\title{
ABSTRAK \\ KOMPETENSI VOKASIONAL DAN KEPEDULIAN LINGKUNGAN DENGAN PEMANFAATAN LIMBAH CAIR INDUSTRI TEMPE DI SMKN 13 KOTA MALANG
}

\begin{abstract}
Husnul Chotimah, Guru SMKN 13 Kota Malang, Villa Bukit Tidar Blok A2/13 081334733113, E-mail: husnulchotimah.67@gmail.com
\end{abstract}

Tujuan penelitian ini adalah mendeskripsikan proses pembuatan nata de soya dengan menggunakan bahan baku limbah industri tempe yang dilakukan oleh peserta didik SMKN 13 Kota Malang. Metode dalam proses pembuatan nata de soya bahan baku limbah industri tempe menggunakan metode eksperimen yang dilakukan di laboratorium. Hasil penelitian menunjukkan bahwa telah dilakukan upaya dalam mengatasi problematika lingkungan khususnya dalam pengelolaan limbah tempe menjadi nata de soya. Pengolahan limbah tempe menjadi nata de soya telah mampu mengembangkan kompetensi vokasional, keterampilan dalam mengolah limbah menjadi sesuatu yang bernilai ekonomis bagi peserta didik jurusan teknologi pengolahan hasil pertanian.

Kata Kunci: kompetensi vokasional, nata de soya, limbah cair.

\section{COMPETENCE AND CARING ENVIRONMENT WITH VOKASIONAL UTILIZATION OF INDUSTRIAL LIQUID WASTE TEMPE IN SMKN 13 MALANG}

The aim of this research is described the process of making nata de soya by the use of the raw material of industrial waste, food done by participants in SMKN 13 Malang. A method of in the process of making nata de soya raw materials industrial wastes tempe use the experimental methods are carried out in a laboratory. The result showed that has been conducted an effort to overcome environmental problems ekspecially in waste management tempe be nata de soya.Waste processing tempe be nata de soya has been able to develop competence vokasional, skill in treating waste into something we consider economical for learners of technology processing of agricultural produce.

Keywords: competence vokasional, nata de soya, liquid waste

Kurikulum 2013 bertujuan untuk pribadi dan warga negara yang beriman, mempersiapkan manusia Indonesia agar produktif, kreatif, inovatif dan afektif memiliki kemampuan hidup sebagai serta mampu berkontribusi pada 
kehidupan bermasyarakat, berbangsa, pendidikan (KTSP). Kegiatan bernegara dan peradaban dunia. pembelajaran harus dapat mendukung Kurikulum 2013 menganut: (1) tumbuh kembangnya pribadi peserta didik pembelajaran yang dilakukan guru (taugh yang berjiwa kewirausahaan dan curriculum) dalam bentuk proses yang mempunyai kecakapan hidup. Oleh sebab dikembangkan berupa kegiatan itu kurikulum perlu memuat kecakapan pembelajaran di sekolah, kelas, dan hidup untuk membekali peserta didik masyarakat; dan (2) pengalaman belajar memasuki dunia kerja. Hal ini sangat langsung peserta didik (learned- penting terutama bagi satuan pendidikan curriculum) sesuai dengan latar belakang, kejuruan dan peserta didik yang tidak karakteristik, dan kemampuan awal melanjutkan ke jenjang yang lebih tinggi peserta didik. Pengalaman belajar (Permendikbud, 2013).

langsung individual peserta didik menjadi

Lulusan SMK utamanya harus hasil belajar bagi dirinya, sedangkan hasil memiliki kompetensi untuk melaksanakan belajar seluruh peserta didik menjadi hasil pekerjaan tertentu, dapat mengembangkan kurikulum (Permendikbud, 2013).

Pada pokok-pokok pikiran diri baik secara vertikal maupun kurikulum pendidikan kejuruan horizontal dan memiliki kecakapan untuk dikemukakan bahwa kurikulum sekolah menjalani kehidupan secara baik. Berdasarkan peraturan menteri pendidikan menengah kejuruan (SMK) harus nasional (Permendiknas) nomor 23 tahun dirancang dan disusun secara dinamis dan 2006, standar kompetensi lulusan satuan fleksibel, agar mampu mengantisipasi dan pendidikan SMK/MAK antara lain: (1) sekaligus mengikuti berbagai memanfaatkan lingkungan secara perkembangan yang terjadi di dunia kerja produktif dan bertanggungjawab, khususnya di dunia usaha dan industri menjaga kesehatan dan keamanan diri, (DU/DI). Prinsip tersebut tentu akan kebugaran jasmani, serta kebersihan mewarnai Kurikulum SMK tahun 2013 lingkungan, dan (3) menguasai yang merupakan hasil penyempurnaan kompetensi program keahlian dan dari kurikulum berbasis kompetensi kewirausahaan baik untuk memenuhi (KBK) dan kurikulum tingkat satuan tuntutan dunia kerja maupun untuk 
mengikuti pendidikan tinggi sesuai limbah adalah masalah internasional yang dengan kejuruannya.

SMKN 13 Kota Malang adalah salah satu sekolah kejuruan di Kota Malang yang memiliki jurusan agribisnis dengan program keahlian teknologi pengolahan hasil pertanian (TPHP). Pada program keahlian TPHP kompetensi dasar kejuruannya antara lain: (1) mengenal komoditas hasil pertanian, (2) mengidentifikasi karakteristik industri pertanian, (3) menerapkan dasar pengolahan dan pengawetan bahan hasil pertanian dan (4) menerapkan keselamatan, kesehatan kerja, dan lingkungan hidup (K3LH). Sedangkan, kompetensi kejuruan meliputi antara lain: (1) menerapkan perlakukan pendahuluan terhadap bahan hasil pertanian pasca panen, (2) mengemas bahan hasil pertanian dan produk olahan, (3) menerapkan sanitasi di lingkungan perusahaan pengolahan hasil pertanian dan (4) mengelola limbah pengolahan hasil pertanian. Dari beberapa kompetensi kejuruan, di SMKN 13 Malang lebih difokuskan pada keterampilan peserta didik dalam mengelola limbah hasil pertanian (baca: industri makanan). Mengapa demikian? Karena masalah (dari pembuangan air, atau WC) kadang 
ada juga limbah pertanian dan/atau industri. Limbah (sering) juga memuat air yang berasal dari air hujan yang mengandung zat dalam bentuk suspensi, larutan dan koloid. Bila dibuang langsung ke lingkungan, limbah dapat membahayakan. Sebagai contoh: limbah bisa menjadi sumber infeksi, mendorong penyebaran penyakit yang disebarkan lewat air seperti kolera dan demam tifoid (http://id.wikipedia.org/wiki/Pengolahan_1 imbah, diakses tanggal 30 Agustus 2013). Pada umumnya industri menghasilkan limbah, baik industri pangan maupun non pangan berupa padatan atau cairan. Seringkali limbah industri tersebut jika tidak ditangani secara baik akan menyebabkan pencemaran lingkungan yang mengganggu keseimbangan ekosistem dan bahkan bisa menjadi penyebab kematian. Di Indonesia, limbah industri pangan seringkali dibuang ke sungai atau area pemukiman sehingga mengganggu lingkungan sekitar, menimbulkan bau tidak sedap, dan mengurangi keindahan lingkungan, bahkan dapat pula menyebabkan kematian habitat. Pembuangan limbah secara sembarangan menunjukkan rendahnya kesadaran masyarakat akan kesehatan lingkungan.

Beberapa industri pangan yang menghasilkan limbah yang sering kali mencemari lingkungan antara lain industri tahu, industri tempe, industri tapioka, industri makanan berbahan baku kelapa, industri makanan berbahan baku nanas, dan berbagi macam industri makanan lainnya, Sedangkan khusus Kota Malang memiliki industri (baca: home industry) tempe yang banyak, sehingga limbah produk makanan tersebut cukup tinggi. Apabila limbah tersebut tidak dicarikan solusi yang efektif, akan mencemari masyarakat khususnya masyarakat sekitar. Salah satu solusi efektif untuk mengatasi limbah industri tersebut adalah dengan mengolahnya menjadi produk yang bernilai ekonomis. Oleh karena itu perlu dikembangkan teknologi proses pengolahan limbah industri pangan menjadi produk bernilai ekonomis (Salim, 2011). Salah satu teknik pengolahan limbah industri pangan menjadi produk ekonomis adalah dengan mengubah limbah industri pangan yang masih mengandung nutrisi tersebut menjadi produk nata. Limbah cair pada industri tempe dapat diolah menjadi produk nata 
de soya, limbah cair tapioka dapat diolah menjadi nata de cassava, limbah air kelapa dapat diolah menjadi nata de coco, dan limbah industri pengolahan nanas menjadi nata de pina. Nata merupakan bahan pangan berupa jeli yang biasa dijadikan sebagai campuran produk minuman instan. Produk nata merupakan produk kaya serat yang baik bagi kesehatan.

Limbah cair yang berasal dari proses perebusan dan perendaman kedelai industri tempe, mempunyai suhu,TDS, TSS, BOD, COD, serta amoniak bebas yang melebihi standar baku mutu limbah cair sehingga dapat mencemari lingkungan (Salim, 2011). Limbah cair berupa air bekas rendaman kedelai dan air bekas rebusan kedelai seringkali masih dibuang langsung pada perairan di sekitarnya. Jika limbah tersebut langsung dibuang ke perairan maka dalam waktu yang relatif singkat akan menimbulkan bau busuk dari gas $\mathrm{H}_{2} \mathrm{~S}$ amoniak, ataupun fosfin sebagai akibat terjadinya fermentasi limbah organik. Adanya proses pembusukan akan menimbulkan bau yang tidak sedap, terutama pada musim kemarau dengan debit air yang berkurang. Ketidakseimbangan lingkungan baik fisik, kimia, maupun biologis dari perairan yang setiap hari menerima beban limbah dari proses produksi tempe mempengaruhi kualitas air dan kehidupan organisme di perairan tersebut.

Limbah cair industri tempe mengandung protein dan karbohidrat yang cukup tinggi. Kandungan protein dan karbohidrat dalam limbah cair tempe tersebut dapat dimanfaatkan untuk menghasilkan produk nata de soya dengan memanfaatkan Acetobacter xylinum. Bakteri ini mengubah karbohidrat dan protein dalam limbah tempe menjadi serat selulosa dengan tekstur yang kenyal. Limbah cair tempe selain mengandung protein juga mengandung vitamin $B$ terlarut dalam air, lestin, dan oligosakarida. Limbah cair tempe menjadi salah satu alternatif bahan baku untuk pembuatan produk nata. Nata berbahan baku limbah kedelai memiliki karakteristik produk yang secara kenampakan sedikit kekuningan, cita rasa yang khas kedelai, kenyal, lebih mudah putus dibandingkan dengan nata de coco yang lebih ulet, serta kandungan seratnya tinggi. Nata de soya adalah makanan yang banyak mengandung serat selulosa kadar tinggi yang bermanfaat bagi kelancaran pencernaan kita. 


\section{METODE PENELITIAN}

Metode dalam proses pembuatan nata de soya dengan menggunakan bahan baku limbah industri tempe yang dilakukan oleh peserta didik SMKN 13 Kota Malang menggunakan laboratorium.

\section{Pengolahan Limbah Cair Tempe di} SMKN 13 Kota Malang

Terkait dengan kompetensi kejuruan khususnya program keahlian teknologi pengolahan hasil pertanian (TPHP) penulis, seorang guru produktif dan tiga peserta didik SMKN 13 Malang melaksanakan survei lapangan dengan mendatangi kantor koperasi unit desa (KUD) pengrajin tempe di desa Sanan Kecamatan LowokWaru Kota Malang dan mendatangi rumah salah satu pengrajin tempe di daerah tersebut.

Dari kantor KUD diperoleh informasi bahwa setiap hari 60 home industry di desa Sanan membuat tempe dari kedelai. Kedelai dibeli melalui KUD tersebut, sehingga setiap hari terjual 120 ton kedelai, tetapi tidak semua industri tempe membeli kedelai di KUD, sehingga tidak diketahui secara pasti jumlah home industry yang tersebar di Kota Malang. Kedelai yang digunakan adalah kedelai impor dengan beberapa variasi kualitas.
Berdasarkan hasil wawancara diketahui bahwa kedelai lokal akan menghasilkan tempe yang lebih baik, enak dan kandungan gizinya lebih tinggi. Karena sulit diperoleh dan harganya mahal, pengrajin tempe memilih kedelai impor untuk memproduksi tempe.

Setelah dari KUD, dilanjutkan dengan mendatangi rumah seorang pengrajin tempe dan di peroleh informasi bahwa proses pembuatan tempe di desa Sanan masih merupakan proses tradisional yang banyak dibantu oleh tenaga manusia. Diperoleh informasi pula bahwa proses pembuatan tempe menghasilkan dua macam limbah yaitu limbah padat dan limbah cair. Limbah padat berasal dari kulit kacang kedelai yang dikupas menggunakan mesin setelah tahap perendaman dan perebusan awal, sedangkan limbah cair berasal dari air rendaman dan rebusan kedelai. Kedua limbah tersebut dapat dimanfaatkan sebagai makanan dan minuman ternak. Tetapi, yang dibuang di alam jumlahnya juga masih banyak.

Proses pembuatan tempe yang menghasilkan limbah ini diawali dengan proses pencucian bahan baku kedelai, kemudian kedelai yang sudah bersih 
direbus selama 2-4 jam lalu dikupas dan dipecah menggunakan mesin. Setelah itu dilakukan proses pemisahan kulit dengan biji kedelai dengan menggunakan air. Selanjutnya kedelai direndam selama 12 jam kemudian dicuci dan ditiriskan untuk proses pendinginan. Jika kedelai sudah dingin diberi ragi, diratakan dan dikemas dengan menggunakan plastik atau daun pisang. Tempe yang telah dikemas didiamkan selama 32 jam untuk siap dikonsumsi.

Dari proses tersebut diperoleh gambaran bahwa pada proses pembuatan tempe ada banyak limbah cair yang dihasilkan, Limbah tersebut ada yang digunakan untuk minum ternak dan sebagian lagi dibuang. Limbah cair yang digunakan sebagai minum ternak adalah limbah perebusan. Proses pembuatan tempe yang memakan waktu beberapa hari seringkali para pengrajin menyiasati untuk menggunakan air rebusan awal kedelai sebagai perebus kedelai tahap kedua setelah perendaman. Hal tersebut dilakukan dengan alasan penghematan air dan penghematan energi. Jadi setelah merebus kedelai bersih, air yang masih panas tersebut digunakan untuk merebus kedelai yang sudah direndam semalam.
Air rebusan yang dihasilkan menurut pengrajin sangat kental dan berlendir, air inilah yang digunakan sebagai minuman ternak.

\section{Pembuatan Nata de soya di SMKN 13 Kota Malang}

Pembuatan nata de soya di laksanakan di laboratorium teknologi pengolahan hasil pangan (TPHP) SMKN 13 Malang. Tahap awal pembuatan nata de soya, peserta didik belajar membuat stater sendiri yaitu"menangkap bakteri" dengan media nanas. Setelah 14 hari masa inkubasi yang paling efektif untuk bakteri Acetobacter xylinum (Nisa, 2012) maka peserta didik membuat nata de soya dari: (a) sisa air rendaman kedelai, (b) sisa air rebusan pertama dan (c) sisa air rebusan kedua. Penulis sengaja menggunakan ketiga limbah tempe (tiga variabel) agar mengetahui limbah yang paling efektif untuk diproduksi menjadi nata de soya juga melatih peserta didik melakukan eksperimen dengan harapan budaya sebagai peneliti tumbuh sejak dibangku SMK. Hal tersebut dapat menumbuhkan kompetensi vokasional seperti yang termaktub dalam kurikulum jenjang SMK. Berikut ini adalah proses pembuatan nata de soya dengan 
menggunakan bahan baku limbah industri tempe yang dilakukan oleh peserta didik SMKN 13 Kota Malang yang dibimbing oleh penulis dan seorang guru produktif. Bahan yang digunakan adalah: $600 \mathrm{ml}$ air limbah kedelai, 1 sdt urea, 1 sdm gula pasir, 1 sdm asam cuka dapur, dan 60 Bibit nata/starter. Adapun proses pembuatannya adalah:

\section{Proses pembuatan}

a. Persiapan Nampan

Menyiapkan nampan sejumlah tiga buah. Nampan yang digunakan ditutup koran dan diikat dengan menggunakan tali rafia.

b. Penyaringan Media

Tiga macam limbah cair industri tempe yang digunakan sebagai media pembuatan nata disaring dengan kain kasa agar kotoran-kotoran dan partikel kasar dapat dipisahkan.

c. Perebusan

Perebusan dilakukan dengan menggunakan panci kapasitas $600 \mathrm{ml}$ (tiga buah) dengan menggunakan kompor gas. menambahkan gula pasir dan asam cuka ke dalam media larutan sambil dilakukan pengaduan. Jika larutan telah mendidih kemudian ditambahkan urea. d. Inkubasi

Larutan yang mendidih kemudian dituang pada nampan-nampan yang telah ditutup dengan menggunakan koran

e. Pemanenan

Setelah pemeraman selama 10 hari, dilakukan permanenan. Nata dengan kualitas baik dan nata terkontaminasi jamur dipisahkan. Nata terkena jamur dilakukan pengguntingan dan dibuang bagian yang terkena jamur.

f. Pencucian

Nata hasil panen kemudian dicuci dengan menggunakan air bersih. Kemudian setelah dicuci bersih dapat disimpan dalam kotak plastik dalam bentuk lembaran atau dipotong-potong dengan menggunakan mesin pemotong atau secara manual dengan menggunakan pisau.

g. Penyimpanan

Nata yang telah menjadi potongan kemudian disimpan dalam kotak plastik dengan penambahan air sampai permukaan nata tertutup air. Perawatan dilakukan dengan cara pergantian air setiap hari. 


\section{HASIL PENELITIAN}

Peserta didik mengamati perubahan yang terjadi pada medium pembuatan nata de soya selama 10 hari.

Hasil pengamatan dapat dilihat pada

Tabel 1. Hasil Pengamatan

\begin{tabular}{|l|l|l|l|}
\hline \multirow{2}{*}{$\begin{array}{c}\text { Hari } \\
\text { ke- }\end{array}$} & \multicolumn{3}{|c|}{ Tebal Lapisan $(\mathrm{cm})$} \\
\cline { 2 - 4 } & Air rendaman & \multicolumn{1}{|c|}{ Air rebusan 1 } & Air rebusan 2 \\
\hline 1 & 0,1 & 0,2 & 0,1 \\
\hline 2 & 0,2 & 0,4 & 0,2 \\
\hline 3 & 0,4 & 0,5 & 0,4 \\
\hline 4 & 0,5 & 0,6 & 0,5 \\
\hline 5 & 0,6 & 0,7 & 0,6 \\
\hline 6 & 0,7 & 0,8 & 0,7 \\
\hline 7 & 0,8 & 0,9 & 0,8 \\
\hline 8 & 0.92 & 0,92 & 0.92 \\
\hline 9 & 0,97 & 0,98 & 0,93 \\
\hline 10 & 1 & 1 & 0,95 \\
\hline
\end{tabular}

\section{PEMBAHASAN}

Nata de soya merupakan jenis makanan hasil fermentasi oleh bakteri Acetobacter xylinum. Acetobacter xylinum dalam pertumbuhan dan aktivitasnya membentuk nata memerlukan suatu media yang tepat memiliki kandungan komponen-komponen yang dibutuhkan sehingga produksi nata yang dihasilkan dapat secara optimal. Komponen media nata yang dibutuhkan sebagai syarat media nata antara lain memiliki sumber karbon dapat berupa gula, sumber nitrogen dapat berupa penambahan urea atau ZA, mineral dan vitamin yang mendukung pertumbuhan bakteri Acetobacter xylinum. Pada fermentasi nata kondisi lingkungan juga sangat berpengaruh karena bakteri Acetobacter xylinum memiliki kondisi optimum lingkungannya untuk tumbuh baik yaitu suhu, $\mathrm{pH}$, cahaya, dan oksigen.

Nata adalah produk fermentasi oleh bakteri Acetobacter xylinum pada substrat yang mengandung gula. Bakteri tersebut menyukai kondisi asam dan memerlukan nitrogen untuk stimulasi aktifitasnya. Glukosa substrat sebagian akan digunakan bakteri untuk aktifitas metabolisme dan sebagian lagi diuraikan menjadi suatu polisakarida yang dikenal dengan "extracelluler selulose" berbentuk gel. Polisakarida inilah yang dinamakan nata (Suarsini, 2010).

Nata terbentuk dari aktivitas bakteri Acetobacter xylinum dalam sari 
buah yang mengandung glukosa yang kemudian diubah menjadi asam asetat dan benang-benang selulosa. Lama-kelamaan akan terbentuk suatu massa yang kokoh dan mencapai ketebalan beberapa sentimeter. Selulosa yang dikeluarkan ke dalam media itu berupa benang-benang yang bersama-sama dengan polisakarida berlendir membentuk jalinan yang terus menebal menjadi lapisan nata. Bakteri Acetobacter xylinum akan dapat membentuk nata jika ditumbuhkan dalam air kelapa yang sudah diperkaya dengan Karbon (C) dan Nitrogen (N), melalui proses yang terkontrol. Dalam kondisi demikian, bakteri tersebut akan menghasilkan enzim akstraseluler yang dapat menyusun zat gula menjadi ribuan rantai serat atau selulosa. Dari jutaan renik yang tumbuh pada air kelapa tersbeut, akan dihasilkan jutaan lembar benangbenang selulosa yang akhirnya nampak padat berwarna putih hingga transparan (Novrischa, 2010).

Berdasarkan hasil pengamatan pada Tabel 1 diperoleh data bahwa pada masing-masing variabel menghasilkan nata dengan ketebalan yang berbeda pada masing-masing hari. Perbedaan ketebalan tersebut tidak terlalu mencolok.
Berdasarkan ketebalan nata yang diperoleh dan tidak ditemukannya jamur pada medium nata, maka berturut turut hasil produksi yang terbaik adalah sisa air rebusan pertama, sisa air rendaman, dan sisa air rebusan kedua. Menurut peserta didik yang melaksanakan proses produksi, perbedaan tersebut kemungkinan disebabkan karena kecerobohan pada saat proses produksi. Penanaman bibit nata pada medium sisa air rebusan kedua dilakukan ketika medium masih dalam keadaan kurang dingin, sehingga bakteri yang ditanam sebagian mati dan tidak bisa memproses pembuatan nata. Sedangkan pada medium sisa air rendaman peserta didik mengakui bahwa mereka tanpa sengaja ketika melakukan pengamatan mengoyang-goyangkan medium yang telah ditanami bibit nata, hal tersebut dapat menghambat kerja bakteri.

Kegiatan proses produksi yang telah dilakukan oleh peserta didik, mereka dapat mengembangkan kompetensi diri sekaligus kepedulian terhadap masalah lingkungan khususnya limbah kedelai yang banyak dihasilkan dari produksi pembuatan tempe di Kota Malang. Pengolahan limbah yang telah dilakukan oleh peserta didik, merupakan salah satu 
alternatif dalam pengelolaan lingkungan yang memberikan dapat ekonomis bagi masyarakat. Kegiatan yang telah dilakukan oleh peserta didik SMKN 13 Kota Malang telah sesuai dengan undangundang nomor 23 tahun 1997, bahwa merupakan kewajiban setiap orang untuk memelihara lingkungan hidup dan mencegah serta menanggulangi kerusakan dan pencemaran. Undang-undang tersebut menyebutkan bahwa pengelolaan lingkungan bertujuan untuk tercapainya keselarasan hubungan antara manusia dengan lingkungan hidup sebagai tujuan membangun manusia Indonesia seutuhnya dan terlaksananya pembangunan berwawasan lingkungan untuk kepentingan generasi sekarang dan yang akan datang. Mengingat setiap orang berkewajiban turut serta dalam pemeliharaaan lingkungan maka kepedulian terhadap lingkungan melalui jalur pendidikan merupakan hal yang perlu memperoleh perhatian.

Pelestarian lingkungan adalah suatu usaha untuk memelihara, mengelola dan memanfaatkan daya alam dan ekosisitem dengan sebaik-baiknya untuk kepentingan jangka panjang. Seseorang akan memiliki kesadaran lingkungan apabila memiliki pandangan/persepsi atau informasi tentang berbagai aspek lingkungan yang mendukung dan kesadaran tersebut akan meningkat sejalan dengan makin banyaknya informasi yang diserap di dalam lingkungan yang terus menerus membinanya. Dengan kata lain makin berkembang persepsi seseorang atau wawasan yang terbina maka, makin menghayati, meyakini dan mengamalkannya dalam kehidupan sehari-hari.

\section{KESIMPULAN}

SMKN 13 telah melakukan upaya dalam mengatasi problematika lingkungan khususnya dalam pengelolaan limbah tempe menjadi nata de soya. Dalam pembuatan nata de soya, peserta didik tidak hanya belajar cara mengatasi limbah yang menjadi salah satu masalah lingkungan tetapi peserta didik juga dilatih berpikir untuk memperoleh pengetahuan (knowledge) tentang masalah lingkungan, terutama masalah di lingkungan di mana mereka tinggal, melatih keterampilannya (skill) dalam mengolah limbah menjadi sesuatu yang bernilai ekonomis, sehingga memotivasi diri dalam berwirausaha dan membangun 
sikap peduli lingkungan serta bekerja keras pantang menyerah (attitude). Pengolahan limbah tempe menjadi nata de soya telah mampu mengembangkan kompetensi vokasional peserta didik SMK jurusan teknologi pengolahan hasil pertanian.

\section{SARAN}

Saran yang dapat dikemukakan pada kesempatan ini ditujukan khususnya kepada pimpinan SMKN 13 Kota Malang bahwa hendaknya kegiatan pengolahan limbah tempe ini menjadi bagian dari kompetensi dasar yang diterapkan pada jurusan TPHP di SMKN 13 Malang, sehingga dihasilkan lulusan SMK yang memiliki knowledge, skill, dan attitude yang diharapkan oleh dunia kerja.

\section{DAFTAR RUJUKAN}

Nisa, Fitri Choirun. 2002. Penurunan Tingkat Pencemaran Limbah Cair (Whey) Tahu Pada Produksi Nata de soya (Kajian Waktu Inkubasi). Jurnal Teknologi Pertanian 3 (2), Universitas Brawijaya. Malang

Novrischa, Dinda. 2010. Nata.http://dindan.blogspot.com/ nata/2010.html, diakses tanggal 2 Nopember 2013.

Permendikbud, Nomor 70 Tahun 2013 tentang Kerangka Dasar dan Struktur Kurikulum.
Salim, Emil. 2011. Dari Limbah Menjadi Rupiah. Andi Press. Yogjakarta Suarsini, Endang. 2010. Bioremediasi Limbah Air Tempe Sebagai Bahan Baku Pembuatan Nata de soya. FMIPA UM. Malang

Zulfikar, Reza. 2010. http://rezazulfikar.blogspot.com/ 2011/04/pemanfaatan-limbah tahu-dan-tempe.html, diakses tanggal 1 september 2013. 